\title{
PEMBUATAN SERBUK KERING PHANEROCHAETE CHRYSOSPORIUM UNTUK PENGOLAHAN LIMBAH TEKSTIL
}

\author{
Nyoman Sri Widari \\ Jurusan Teknik Kimia \\ Universitas WR. Supratman Surabaya \\ Email : dewiprasetyaningtyas@gmail.com
}

\begin{abstract}
Abstrak
Dhanerochaete chrysosporium (P. chrysosporium) merupakan jamur pelapuk putih yang terdapat pada kayu, mempunyai kemampuan mendegradasi warna, sampah, dan limbah tekstil. Selama ini pemanfaatan (P. chrysosporium) digunakan dalam bentuk fresh mycelia, tetapi kondisi seperti ini memiliki keterbatasan yaitu daya tahan rendah. Untuk itu diperlukan suatu cara untuk pengawetan agar tidak terjadi kontaminasi, utasi dan kematian. Dan untuk memperudah transportasi, distribusi dalam jarak jauh tanpa kehilangan aktivitasnya, diperlukan mediam pembawa sehingga produk berupa serbuk kering.

Inokulum P. chrysosporium diinokulasikan dalam NLM (Nitrogen Limited Media) dan diinkubasi selama 4 hari. Lalu ditambahkan media pembawa padat ( tepung gaplek dan campuran tepung gaplek dengan jagung).

Hasil penelitian didapat bahwa tepung jagung dan gaplek berpotensi untuk dijadikan serbuk kering bermuatan P. chrysosporium, media pembawa padat tepung gaplek dan jagung mempunyai kemampuan mengurangi COD limbah tekstil. \% reduksi COD terbesar pada media pembawa gaplek dengan sesudah masa simpan 1 bulan pada ratio 1:0,8 sebesar 57,58 dengan kadar air 15,09\% dan \% reduksi COD media pembawa campuran gaplek dan jagung dengan sesudah masa simpan 1 bulan pada ratio 1:1,4 sebesar 29,95\% dengan kadar 17,7\%
\end{abstract}

\section{Kata Kunci : Serbuk kering P. chrysosporium}

\section{PENDAHULUAN}

\section{Latar Belakang}

Phanerochaete chrysosporium (P. chrysosporium) merupakan jamur pelapuk putih yang terdapat pada kayu, mempunyai kemempuan mendegradasi warna, sampah, dan limbah tekstil. Selama ini pemanfaatan ( $P$. chrysosporium) digunakan dalam bentuk fresh mycelia, tetapi kondisi seperti ini memiliki keterbatasan yaitu daya than rendah karena kadar air pada media yang ditumbuhi fresh mycelia relative cukup tinggi. Untuk itu diperlukan suatu cara untuk pengawetan agar tidak terjadi kontaminasi, mutasi, dan kematian.

Salah satu metode penghilangan air pada fresh mycelia adalah dengna menggunakan pengering beku (freeze dryer). Kandungan air yang relative rendah menyebabkan $P$. chrysosporium lebih lama bertahan atau awet. Dan untuk mempermudah transportasi, distribusi dalam jarak jauh tanpa kehilangan aktivitasnya, diperlukan media pembawa sehingga produk berupa produk kering.
Oleh karenaitu, perlu dilakukan penelitian umtuk meihat pengaruh media pembawa yang bermuatan $P$. chrysosporium terhadap kemampuannya setelah dikeringkan dengan freeze dryer. Sebagai uji kemampuan $P$. chrysosporium, maka digunakan limbah tekstil yang banyak mengandung pewarna sintetis. P. chrysosoprium diharapkan mampu mendegradasi pewarna sintetis dengan melihat $\%$ reduksi CODnya.

\section{Rumusan Masalah}

Bagaimana pengaruh jenis media pembawa dan rasio media pembawa padat terhadap cair, waktu pengeringan serta lama penyimpanan terhadap daya tahan jamur $P$. chrysosporium dengan melihat kemampuannya mendegradasi limbah tekstil.

\section{Tujuan Penelitian}

Tujuan dari penelitian ini adalah membuat serbuk kering bermuatan $P$. chrysosporium dengan melihat kemampuannya mendegradasi limbah 
tekstil.

\section{TINJAUAN PUSTAKA}

\section{Phanerochaete Chysosporium}

Mikroba yang digunakan adalah jamur pelapuk putih $P$. chrysosporium. Jamur ini umumnya terdapat pada kau dan merupakan jenis tumbuhan yang berkembang biak dengan spora.

Jamur merupakan mikroorganisme bersel banyak, hidup secara aerobik, nonfotosintetik kemoheterotrof dan termasuk eukariotik. Mikroba ini menggunakan senyawa organik sebagai substrat dan bereproduksi secara aseksual dengan spora. Kebutuhan metabolisme mereka sama seperti bakteri, namun membutuhkan lebih sedikit nitrogen dan dapat tumbuh dan berkembang biak pada $\mathrm{pH}$ rendah. Ukuran jamur lebih besar dari pada bakteri, tetapi mempunyai karakteristik pengendapan yang buruk. Oleh karena itu mikroorganisme ini tidak disukai dalam proses activated sludge (lumpur aktif).

Faktor utama yang mempengaruhi pertumbuhan jamur ini adalah suhu, $\mathrm{pH}$, kandungan oksigen terlarut dan konsentrasi nitrogen yang mencukupi. Temperatur optimum yang mendukung pertumbuhan jamur ini adalah $39^{\circ} \mathrm{C}$ dengan $\mathrm{pH}$ antara $4-5$. Karena mikroorganisme ini termasuk aerobik, maka aktivitas biologisnya juga dipengaruhi oleh konsentrasi oksigen terlarut dalam media (Ceribasi dan Yetis, 2001).

P. chrysosporium termasuk dalam:

Divisi : Eumycota

Sub divisi : Basidiomycota

Class : Hymenomycetes

Sub class : Holobasidiomycetidae

Genus : : Sporotricum (Phaneorochaete)

Species : Chrysosporium

Jamur ini memproduksi enzim ekstraseluler yang dapat mendegradasi polimer aromatic komplek dialam yaitu lignin. Jamur pelapuk putih mempunyai kemampuan untuk mendegradasi warna dengan cara mengubah ikatan aromatic pewarna. Mikroba ini tidak dapat menggunakan secara langsung enzim yang digunakan sebagai sumber energy, substrat lain se[erti glukosa dan karbon harus ditambahkan. Pada fase pertumbuhannya, mikroba ini juga membutuhkan nitrogen dalam konsentrasi tertentu.

\section{Fase Pertumbuhan}

Pertumbuhan mikroba berhubungan dengan jumlah sel hidup yang ada, substrat, keterbatasan nutrient yang ada, dan faktor lainnya seperti $\mathrm{pH}$, tempertaur, tipe dan konsentrasi substrat, skseptor hydrogen, jumlah dan konsentrasi nutrient penting deperti nitrogen, fosfor, sulfur, dan lain sebagainya, mineral esensial, tekanan osmosis, sifat racun dari media atau by product serta tingkat pencampuran. Suatu spesies tunggal mikroba diinokulasikan kedalam medium yang menganduang semua substansi yang diperlukan untuk pertumuhannya, akan terjadi fase pertumbuhan sebagai berikut:

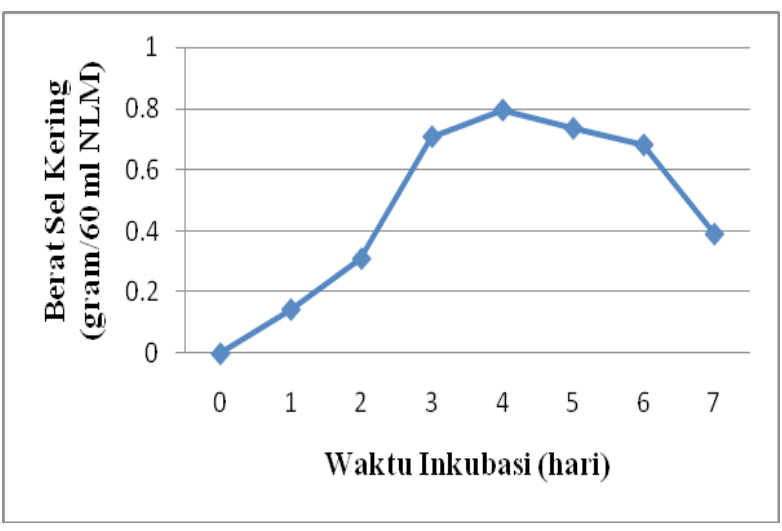

\section{Gambar Kurva Pertumbuhan Mikroba}

1. Fase lag/penyesuaian diri

Fase ini merupakan fase penyesuaian mikroba ke suatu lingkungan baru. Pada fase ini tidak ada penambahan jumlah sel, melainkan peningkatan ukuran atau besar sel.

2. Fase logaritmik

Selama fase ini jumlah sel ini meningkat.

3. Fase stasioner

Dalam fase ini kecepatan tumbuh sama denga kecepatan mati sehingga jumlah sel konstan.

4. Fase kematian

Pada fase ini terjadi akumulasi bahan toksik, zat hara yang diperlukan olrh mikroba juga berkurang, sehingga mikroba akan memasuki fase kematian. Jumlah sel akan 
menurun terus sampai disapatkan jumlah sel yang konstan untuk beberapa waktu. Fase ini dapat dilihat pada gambar diatas.

\section{Media Pembawa}

Ada tiga cara penyimpanan yang lazim dilakukan di laboratorium, yaitu penyimpanan dingin dalam tabung, pengeringan pada bed porcelain, dan liofilasi. Cara pertama adalah cara yang sederhana dan yang terakhir adalah cara yang paling kompleks. Jangak waktu starin dapat disimpan dalam keadaan stabil dan hidup, terlama liofilasi, kemudian pengeringan pada bed porcelain, dan tersingkat penyimpanan dingin pada tabung. Cara penyimpanan lain yang dapat memudahkan transportasi dan distribusi yaitu dengan menggunakan media pembawa.

Penambahan media pembawa pada pengawetan suatu mikroba dapat mempertahankan viabilitas dan memperkuat dinding sel mikroba tersebut. Media pembawa yang dipergunakan berupa tepung dengan kandungan nitrogen terbatas yang baik bagi pertumbuhan $P$. chrysosporium.

\section{Media Pengawetan}

Pada umumnya teknologi pengawetan dapat dilakukan dengan berbagai cara, diantaranya pembekuan dan pengeringan.

\section{Pembekuan}

Lapisan pelindung yang paling sederhana untuk suatu bahan adalah lapisan es. Sistem ini terdiri dari suatu pelapisan es yang meliputi komoditi yang dibekukan. Namun pengawetan jenis ini memiliki kesulitan dalam hal pengemasan.

\section{Pengeringan}

Pengeringan adalah proses pengeluaran air dari suatu bahan dengan kondisi terkontrol untuk menghasilkan produk kering dengan kerusakan minimal. Dengan pengeringan akan memperpanjang masa simpan dan mengurangi berat serta volume bahan.

Metode yang cocok digunakan untuk pengeringan mikroba adalah pengeringan beku (freeze drying). Pengeringan model ini menggunakan vakum yang tinggi, sehingga sifat fisik suatu substrat bahan dapat diatur pada suatu titik kritik yang memungkinkan berhasilnya suatu proses pengeringan. Pada umumnya mikroba tidak dapat berkembang dengan kadar air dibawah 18\%, 52 sedangkan pada kadr air diatasnya, mikroba dapat tumbuh dan berkembang dengan pesat.

Freeze drying merupakan salah satu metode pengeringan dengan cara memindahkan air dari keadaan beku menjadi uap dengan sublimasi dibawah kondisi vakum dimana kondisi suhu dan uap air dibawah triple point air. Metode ini mempunyai keuntunga sebagai metode pengeringan yang menghasilkan produk dengan kualitas tinggi dibandingkan metode pngeringan lain. Selama proses pengeringan, suhu yang digunakan relative rendah, sehingga tidak terjadi reaksi kimia atau biokimia, bahan tidak mengalami perubahan tekstur dan zat-zat yang terkandung dalam bahan tidak hilang.

\section{Limbah Tekstil}

Produksi limbah cair industri tekstil yang bersumber dari proses pewarnaan, pemintalan, penenunan, dan pencelupan yang sangat berbahaya bagi lingkungan. Hal ini disebabkan antara lain kandungan BOD dan COD karena tingginya konsentrasi zat warna yang dihasilkan dari limbah cair. Contoh pewarna sintetis yang digunakan yaitu azo, indigo, anthraquinon, dan phtalocianine. Zat warna ini dapat menganggu transmisi cahaya dan menyebabkan turunnya kadar oksigen terlarut dan pH menjadi asam.

\section{Penentuan Chemical Oxygen Demand (COD)}

COD merupakan salah satu parameter untuk mengetahui adanya suatu pencemaran yang disebabkan oleh air limbah. Penetapan COD didasarkan pada kenyataan bahwa hampir semua senyawa organik dapat dioksidasi dengan bantuan oksidator kuat dalam kondisi asam, dimana bahan organic dioksidasi oleh bikromat yang pada saat bersamaan akan tereduksi. Hasil penetapan COD banyak digunakan untuk pengukuran beban pencemaran dari suatu air buangan rumah tangga dan buangan industri.

\section{METODOLOGI PENELITIAN}

\section{Batasan Masalah}

Untuk memperoleh hasil serbuk kering yang baik ditinjau dari waktu penyimpanan terhadap daya tahan serbuk kering dengan melihat kemampuannya mendegradasi limbah tekstil, maka diperlukan variabel-variabel yang sangat 
berpengaruh saat pembuatan.

Lama penyimpanan

\section{Variabel percobaan yang digunakan}

Jenis media pembawa

Kondisi yang dibuat tetap

Rasio media pembawa padat terhadap cair

Suhu pengeringan

Waktu pengeringan

Limbah tekstil

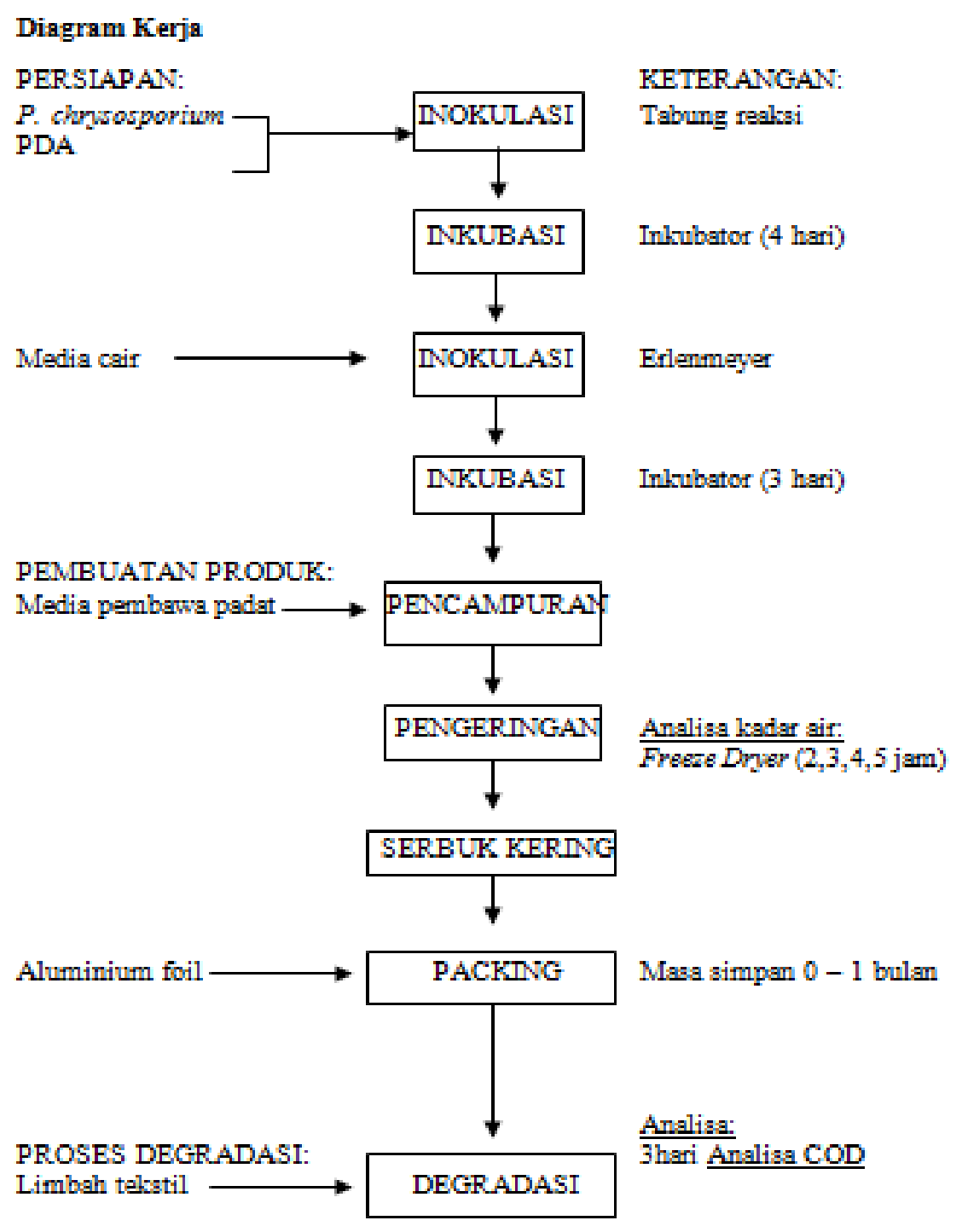

Prosedur Kerja

\section{a. Regenerasi $P$. chrysosporium}

Membuat media padat dari bahan PDA (Potato Dextrose Agar)

Dibuat media pengembangbiakan untuk $P$. chrysosporium yaitu PDA. Komposisi PDA:

- Kentang

200 gram

- $\mathrm{CaCO}_{3}$

0,2 gram
- $\mathrm{MgSO}_{4} \cdot 7 \mathrm{H}_{2} \mathrm{O} \quad 0,2$ gram

- Agar 18 gram

- Dextrose 20 gram

- Aquades 1 liter

Cara pembuatan PDA yaitu kentang diris tipis-tipis dan direbus sampai lunak, dicampur dengan air dan disaring. Kedalam air saringan ditambah bahn lain selain dextrose, dipanaskan lagi smapai agar larut kemudian ditambahkan 
dextrose dan disterilkan dengan autoclave $121^{\circ} \mathrm{C}$ selama 15 menit. Selanjutnya didiamkan dalam posisi miring sampai menjadi padat.

\section{Menumbuhkan $P$. chrysosporium dari kultur murni pada PDA}

Biarkan jamur diinokulasi pada PDA dan diinkubasi pada suhu kamar sekitar $4-7$ hari.

\section{b. Pembuatan media cair NLM (Nitrogen Limited Media)}

Media cair yang digunakan dengan komposisi yang mengandung nutrisi dan nitrogen yang terbatas. Komposisi media cair yang digunkan yaitu:

- NPK

- $\mathrm{MgSO}_{4} \cdot 7 \mathrm{H}_{2} \mathrm{O}$

- $\mathrm{CaCl}_{2}$

- Vitamin B1 (Thiamin) $0.001 \quad$ gram/L pelarut

- Glucose

10 gram/L pelarut

Cara pembuatan NLM yaitu semua bahan dicampur dengan aquades sampai volume mencapai $1 \mathrm{~L}$ pelarut (aquades). Selanjutnya disterilisasi dengan autoclave $121^{\circ}$ selama 15 menit.

\section{c. Penyiapan Inokulum}

Biarkan jamur pada PDA diambil 2 ose, dimasukkan dalam $200 \mathrm{ml}$ NLM dan diinkubasi selama 4 hari. Untuk regenerasi selanjutnya, $10 \%$ inokulum yang terbentuk diinokulasikan pada NLM kemudian diinkubasi selama 3 hari dengan pengocokan.

\section{d. Pembuatan kurva pertumbuhan}

Metode yang digunakan yaitu metode berat kering. Setiap hari diambil sampel jamur $60 \mathrm{ml}$ yang telah diinokulasikan dalam NLM, biomassa jamur dipisahkan dengan centrifuge dengan kecepatan 1000 rpm selama 30 menit dan dikeringkan dalam oven bersuhu $100^{\circ} \mathrm{C}$. sehingga diperoleh berat keringnya.

\section{e. Persiapan media pembawa}

Pada pembuatan serbuk kering bermuatan jamur $P$. chrysosporium dibutuhkan media pembawa. Medai pembawa yang digunakan yaitu tepung gaplek dengan campuran tepung gaplek dengan jagung yang sudah disangrai dan disaring dengan ukuran 315 Mess. Perbandingan media pembawa campuran tepung gaplek dengan jagung adalah 3:1. Media pembawa yang sudah siap, dicampurkan dengan inokulum dalam media cair (3.4.3). Perbandingan antara media pembawa cair dengan media pembawa padat adalah $1: 0,8 ; 1: 1 ; 1: 1,2 ; 1: 1,4$.

\section{f. Metode pengeringan}

Produk yang dihasilkan (3.4.5) berupa pasta dengan kadar air yang cukup banyak, sehingga perlu pengeringan. Alat pengering yang digunakan adalah freeze dryer dengan suhu operasi $37-39^{\circ} \mathrm{C}$, tekanan vakum 16 cmHg, dan waktu 2;3;4;5 jam.

\section{g. Degradasi limbah tekstil}

Limbah tekstil awal diukur CODnya. Untuk mendegradasi limbah tekstil, maka 10 gram serbuk kering yang bermuatan $P$. chrysosporium ditambhakan kedalam 100 $\mathrm{ml}$ limbah tersebut, setelah 3 hari diuji lagi CODnya. Selisih COD sebelum dan sesudah penambahan serbuk kering merupakan \% reduksi CODnya.

\section{h. Packing}

Setelah melalui proses pengerimgan, serbuk kering dikemas untuk menghindari kontaminasi dari lingkungan. Produk sebaiknya dijaga dalam wadah kedap udara atau air dan tidak tembus cahaya. Packing yang digunakan yaitu aluminium foil.

\section{i. Analisa}

Analisa yang dilakukan meliputi analisa kadar air untuk serbuk kering bermuatan $P$. chrysosporium dan analisa COD untuk limbah tekstil./Untuk media pembawa padat tepung gaplek dan jagung dilakukan analisa kadar awal, protein, dan lemak.

\section{HASIL DAN PEMBAHASAN}

Untuk menghasilkan serbuk kering bermuatan P. chrysosporium, digunakan dua jenis media pembawa padat, yaitu:

- Tepung gaplek 
- Campuran tepung gaplek dan tepung jagung dengan perbandingan 3:1

Hasil analisa kimia media pembawa

\begin{tabular}{|l|c|c|c|c|}
\hline $\begin{array}{c}\text { Jenis } \\
\text { Media } \\
\text { Pembawa }\end{array}$ & $\begin{array}{c}\text { \% } \\
\text { Protein }\end{array}$ & $\begin{array}{c}\text { \% } \\
\text { Lemak }\end{array}$ & $\begin{array}{c}\text { Air } \\
\text { Air }\end{array}$ & $\begin{array}{c}\% \\
\text { Abu }\end{array}$ \\
\hline Jagung & 12,170 & 5,232 & 12,024 & 2,251 \\
\hline $\begin{array}{l}\text { Tepung } \\
\text { gaplek }\end{array}$ & 2,525 & 0,674 & 11,912 & 1,783 \\
\hline
\end{tabular}

Media pembawa padat ditambahkan media cair dengan rasio $1: 0,8 ; 1: 1 ; 1: 1,2 ; 1: 1,4$. Sedangkan waktu pengeringan pada freeze dryer 2;3;4;5 jam.

Hasil serbuk kering tersebut dianalisa kadar airnya dan diuji kemampuannya untuk mendegradasi limbah tekstil yang dapat dilihat pada penurunan CODnya.

Kurva pertumbuhan $P$. chrysosporium

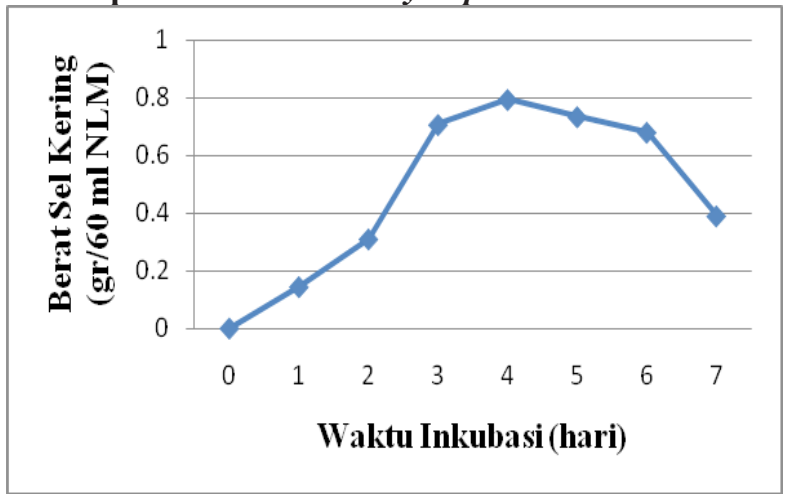

Grafik 1. Kurva Pertumbuhan $\boldsymbol{P}$. chrysosporium

Dari grafik, dapat terlihat bahwa fase logaritma pada waktu inkubasi hari ke 2 sampai 3. Fase stasioner pada hari ketiga sampai kelima yang diikuti fase kematian dengan berkurangnya berat kering sel setelah hari kelima. Berat sel kering tertinggi tepatnya pada fase stasioner pada hari keempat. Pada grafik tersebut terlihat 0,7935 gram/60 ml media cair. Faktor utama yang mempengaruhi pertumbuhan jamur ini adalah suhu, $\mathrm{pH}$, jumlah oksigen terlarut dan konsentrasi nitrogen yang mencukupi. Temperatur optimum yang mendukung pertumbuhan jamur ini adalah 37 $-39^{\circ} \mathrm{C}$. Jamur ini dapat tumbuh pada $\mathrm{pH} 4-7$ dan membutuhkan lebih sedikit nitrogen.

\section{Pengaruh media pembawa terhadap kadar air}

Pertumbuhan mikroorganisme bergantung pada ketersediaan air. Dalam metode pengawetan, metode air diturunkan sehingga tidakk memberikan kesempatan mikroba untuk cukup tumbuh dalam media pembawa. Pengertian media pembawa pada topic ini adalah serbuk kering yang bermuatan $P$. chrysosporium.

Kadar air media pembawa padat sebelum proses pengeringan

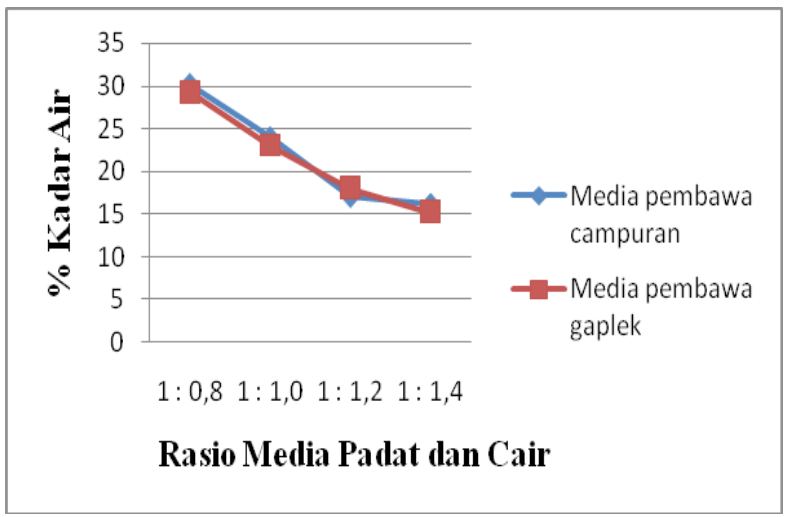

Grafik 2. Hubungan \% kadar air terhadap penambahan media pembawa padat sebelum pengeringan

Berdasarkan grafik tersebut, terlihat bahwa kadar air kedua jenis media pembawa sebelum proses pengeringan mempunyai harga yang hampir sama. Tetapi kadar air media campuran sedikit lebih tinggi diatas media gaplek, karena didalam campuran terdapat jagung dimana pada hasil analisa media pembawa, disebutkan bahwa kadar air tepung jagung lebih tinggi daripada tepung gaplekPada rasio $1: 1,4$ kadar air media pembawa gaplek $15,2 \%$ sedangkan media pembawa campuran $16,18 \%$.

\section{Kadar air media pembawa sesudah proses pengeringan dengan masa simpan 0 bulan}

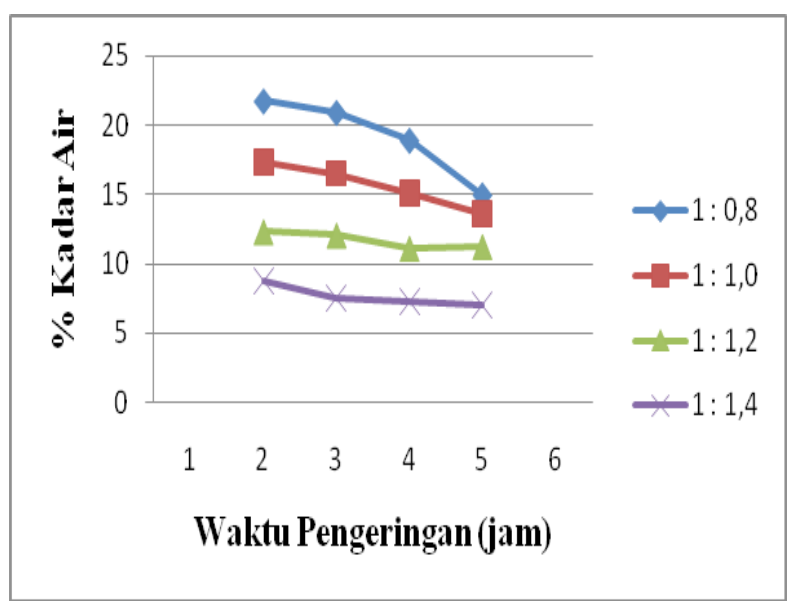

Grafik 3. Hubungan \% kadar air media pembawa gaplek terhadap waktu pengeringan dengan masa simpan 0 bulan 


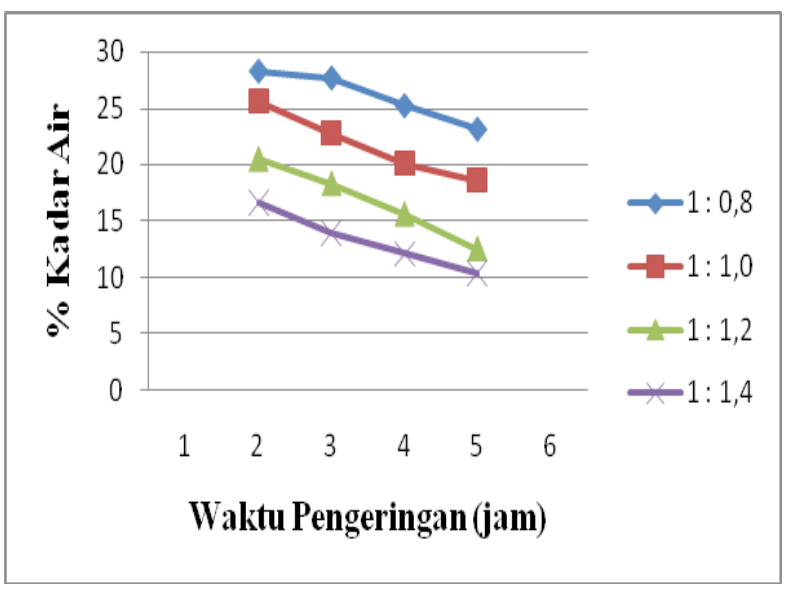

Grafik 4. Hubungan \% kadar air media pembawa campuran gaplek dan jagung terhadap waktu pengeringan dengan masa simpan 0 bulan

Terlihat pada kedua grafik tersebut bahwa pada rasio media pembawa besar dan waktu pengeringan yang lama menghasilkan kadar air yang lebih kecil dari yang lain. Semakin lama waktu pengeringan maka semakin banyak jumlah masa cairan yang diuapkan dari permukaan bahan, sehingga kadar air yang terkandung semakin kecil. Sedangkan pada proses freeze dryer, waktu pengeringan yang lama mengakibatkan proses sublimasi yang besar maka banyak uap air yang ditarik oleh vakum. Pada kedua grafik tersebut dapat dibaca bahwa pada rasio 1 : 1,4 dan waktu pengeringan 5 jam kadar air media pembawa campuran $10,4 \%$ sedangkan media pembawa gaplek 7,005 \%.

Dengan perlakuan yang sama, kedau grafik menunjukkan kadar air yang berbeda. Kadar air pembawa campuran lebih tinggi dari air pembawa gaplek. Proses pengeringan dipengaruhi oleh kadar air awal bahan, ukuran awal bahan, dan porositas bahan. Tepung jagung memiliki daya ikat molekulmolekul lebih tinggi dibanding tepung gaplek.

Kadar air media pembawa gaplek sesudah proses pengeringan dengan masa simpan 1 bulan

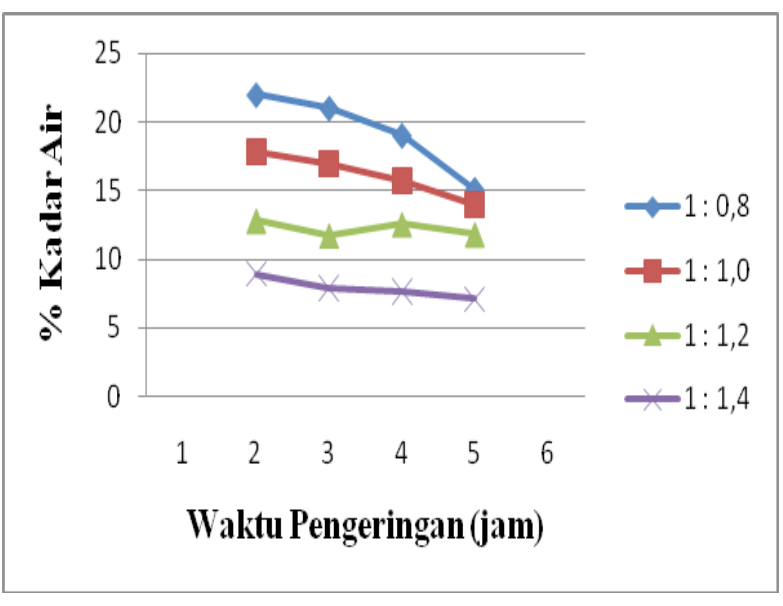

Grafik 5. Hubungan \% kadar air media pembawa gaplek terhadap waktu pengeringan dengan masa simpan 1 bulan

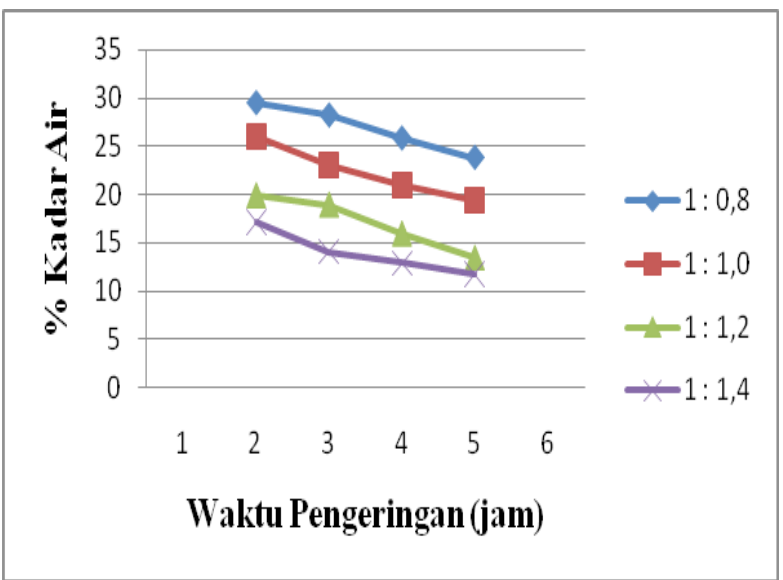

Grafik 6. Hubungan \% kadar air media pembawa campuran gaplek dan jagung terhadap waktu pengeringan dengan masa simpan 1 bulan

Pada masa simpan satu bulan, kadar air kedua media pembawa mengalami sedikit kenaikan dari masa simpan 0 bulan ditunjukkan oleh grafik 5 dan 6. Untuk media pembawa gaplekk dengan rasio 1 : 1,4 waktu pengeringan 5 jam kadar air bertambah dari $7,005 \%$ pada bulan 0 menjadi $7,09 \%$ pada 1 bulan, begitu pula pada media pembawa campuran dari $10,4 \%$ menjadi $11,7 \%$. Hal ini disebabkan oleh faktor lingkungan yang dapat mempengaruhi bertambahnya kadar air. Penyimpanan dalam wadah yang tidak kedap udara bisa mengakibatkan pertambahan volume air dalam bahan. Suatu bahan sudah mencapai kadar air yang minimum, kadar airnya bisa meningkat bila kontak dengan media atau udara karena mengalami kadar air keseimbangan. 
Pengaruh media pembawa terhadap \% reduksi COD

Pengaruh media pembawa terhadap \% reduksi COD dengan masa simpan 0 bulan

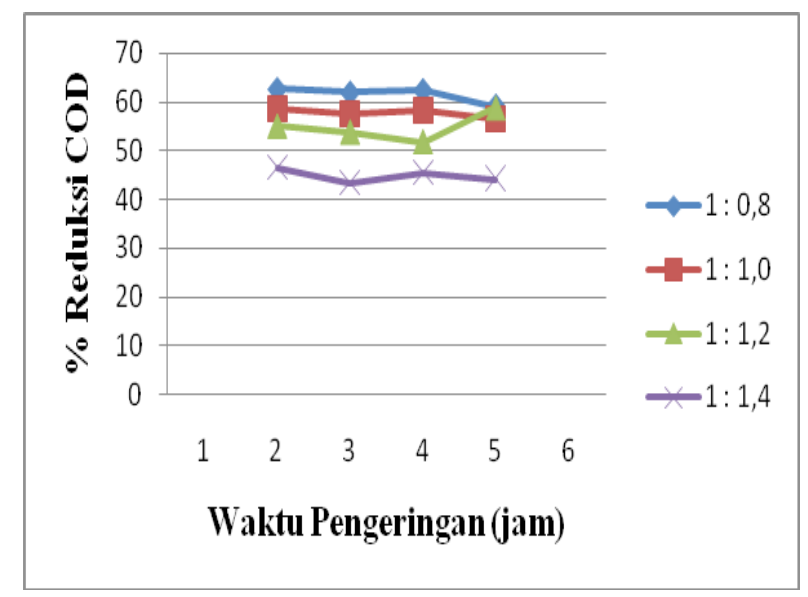

Grafik 7. Hubungan \% reduksi COD media pembawa gaplek terhadap waktu pengeringan dengan masa simpan 0 bulan

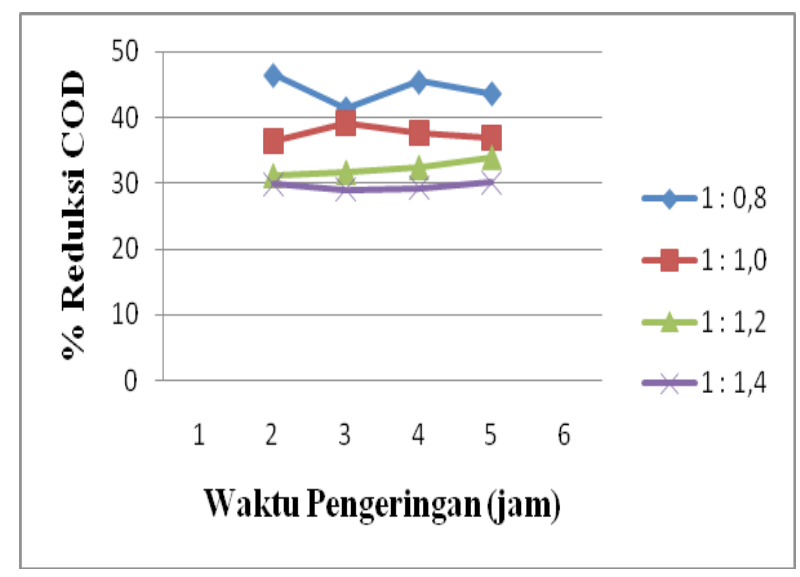

Grafik 8. Hubungan \% reduksi COD media pembawa campuran gaplek dan jagung terhadap waktu pengeringan dengan masa simpan 0 bulan.

Pada grafik 7 terlihat bahwa media pembawa gaplek mempu mereduksi COD, dimana kemampuan terbesar diperoleh pada rasio $1: 0,8$ dengan komposisi media cair terbanyak. Sedangkan nilai $\%$ reduksi untuk tiap waktu pengeringan cenderung stabil. Perbedaan waktu pengeringan tidak terlalu berpengaruh pada \% reduksi untuk bulan ke 0 . Hal ini juga terlihat pada grafik 8 , ini berarti bahwa semakin besar jumlah cairan dalam media pembawa maka semakin banyak inokulum yang terdapat didalamnya, sehingga limbah akan mudah terdegradasi. Jumlah inokulum yang cukup banyak melepaskan enzim.

Dari grafik 7 dan 8 dapat dibandingkan \% reduksi media pembawa gaplek dengan campuran, terlihat bahwa \% reduksi COD gaplek lebih besar dari campuran, misalnya untuk rasio $1: 0,8$ dan waktu pengeringan 2 jam, $\%$ reduksi gaplek $62,63 \%$ sedangkan campuran $46,46 \%$. Sesuai dengan teori, disebutkan bahwa jamur $P$. chrysosporium mamapu hidup dalam lingkungan nitrogen yang terbatas. Pada hasil analisa pembawa, diketahui bahwa kadar protein untuk jagung $12,17 \%$ sedangkan gaplek 2,525\%. Besarnya kadar protein sebanding dengan kadar nitrogen, jika protein besar maka nitrogen juga besar. Jadi padakadar protein yang tinggi, jamur ini tidak dapat tumbuh dengan baik karena hanya memerlukan jumlah nitrogen yang terbatas (Nitrogen Limited Media).

\section{Pengaruh media pembawa terhadap \% reduksi COD dengan masa simpan 1 bulan}

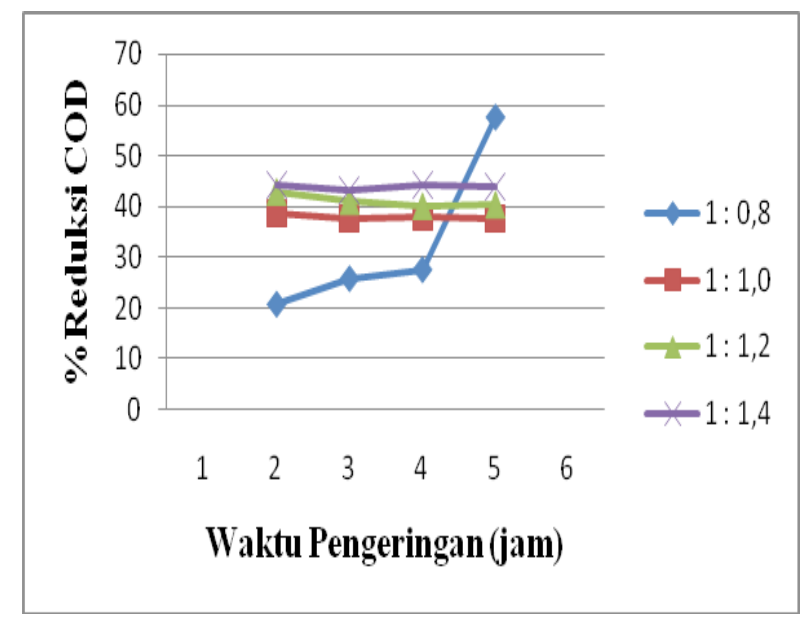

Grafik 9. Hubungan \% reduksi COD media pembawa gaplek terhadap waktu pengeringan dengan masa simpan 1 bulan.

Dari grafik 9, terlihat bahwa \% reduksi COD mengalami penurunan pada waktu pengeringan 2 , 3 , dan 4 jam, misalnya pada pengeringan 2 jam, pada bulan 0 mampu mereduksi COD hingga $62,3 \%$, pada bulan 1 mengalami penurunan menjadi $20,71 \%$, sedangkan pada pengeringan 5 jam hanya sedikit mengalami penurunan yaitu dari $59,09 \%$ menjadi 57,58\%. Hal ini dikarenakan kadar air pada pengeringan 2,3 , dan 4 jam masih besar yaitu $18,88 \%$ - 21,73\%, sedangkan pada pengeringan 5 jam kadar air 14,93\%. Dengan kandungan air yang cukup banyak, dimungkinkan akan mudah 
terkontaminasi dengan mikroba lain. Mikroba sulit tumbuh pad akadar air kurang dari $18 \%$. Hal ini juga berlaku pda rasio $1: 1$, rasio $1: 1,2$, dan rasio $1: 1,4$ yang dapat diamati pada grafik 10 , tetapi pada kondisi serbuk masih awet karena kadar air yang masih sedikit, terlihat dari tidak adanya penurunan yang berarti pada pengukuran bulan 1 . Perbandingan antara \% reduksi untuk masa simpan 1 bulan pada media gaplek rasio $1: 0,8$ dengan kadar air dapat dilihat pada grafik 7 .

\section{KESIMPULAN}

Tepung gaplek dan jagung berpotensi untuk dijadikan serbuk kering bermuatan $P$. chrysosporium.

Media pembawa padat tepung gaplek dan jagung mempunyai kemampuan mengurangi COD limbah tekstil.

Persen reduksi COD terbesar pada media pembawa gaolekk sesudah masa simpan 1 bulan pada ratio $1: 0,8$ sebesar $57,58 \%$ dengan kadar air $15,09 \%$.

Persen reduksi COD terbesar pada media pembawa campuran gaplek dan jagung sesudah masa simpan 1 bulan pada ratio 1 : 1,4 sebesar $29,95 \%$ dengan kadar air $17,7 \%$.

\section{DAFTAR PUSTAKA}

Desrosier, N. W. Teknologi Pengawetan Pangan. Universitas Indonesia, Jakarta, 1988.

Dwidjoseputro, D. Dasar-Dasar Mikrobiologi. Djambatan, Malang, 1964.

Nana, D, Tanti, Melia R. Biosorpsi Logam Berat Plumbum $(\mathrm{Pb})$ Menggunakan Biomassa Phanerochaete chrysosporium. Jurusan Teknik Kimia UPN Veteran, Jawa Timur, Jurnal Ilmiah Teknik Lingkungan Vol 1 No. 2.

Soepriyanto, Bambang A., Ryan F. Biosorpsi Ion Logam Berat dalam Menggunakan Biomassa Phanerochaete chrysosporium. Jurusan Teknik Kimia ITS.

Suharto. Teknologi Pengawatan Pangan. Rineka Cipta. Jakarta. 1991.

Syamsulbahri. Pengaruh Media Pembawa terhadap Kemampuan Hidup Strain Rhizobium Tanaman
Kedelai. Jurnal Penelitian Ilmu-Ilmu Hayati Vol 9, No 2. Malang, 1997.

Taib, G., G. Said., dan S. Wiraatmadja. Operasi Pengeringan pada Pengolahan Hasil Pertanian. PT Mediayatma Sarana Perkasa. Jakarta. 1988.

Winarno, F. G. Kimia Pangan dan Gizi. PT Gramedia Pustaka Utama. Jakarta. 1997.

http://www.emitech.co.uk/freeze-dryer-k750x. htm. The K750X Freeze Dryer with Peltier Cooling and Warming Stag.

http://shantybio.transdigit.com. Pengolahan dan Pemanfaatan Limbah Tekstil.

http;//digilib.ampl.or.id/detail/detail.php. $\quad$ Studi Penyisihan Senyawa Kloralignin oleh $P$. chrysosporium dengan Penambahan Jerami sebagai Kosubstrat.

http://www.sciencedirect.com/scene. Decolourisation of Polymeric Dye by Selected Fungal Strain in Liquid Cultures.

http://rachdie.blogsome.com/2006. Prinsip Pertumbuhan Bakteri.

http://genome.jgi-psf.org/whiterot1/whiterot1. home.html. Phanerochaete Chrysosporium.

http;//botit,botany,wise.edu/toms fungi/1997. $\underline{\mathrm{html}}$. This Mont's Fungus is Phanerochaete Chrysosporium, a Crust Fungus Important in Biotechnology. 